\title{
NOTÍCIA DAS TESES DEFENDIDAS E DISSERTAÇÕES APRESENTADAS EM 2002 E DAS PESQUISAS EM ANDAMENTO EM 2003
}

\section{Teses de doutorado (pelo mês de defesa)}

f e v e reiro:

Maria Cecília de Miranda Nogueira Coelho. Problemas de ética e linguagem em algumas peças de Eurípides.

Orientadora: Profa. Dra. Filomena Yoshie Hirata.

a b r i l:

Juvino Alves Maia Júnior. Platão e Aristóteles no De republica de Cícero.

Orientador: Prof. Dr. Ariovaldo Augusto Peterlini.

a g o s t o:

Anise de Abreu Gonçalves d'Orange Ferreira. A psique e as paixões nos Oneirokritika de Artemidoro.

Orientadora: Profa. Dra. Filomena Yoshie Hirata.

Sandra Maria Gualberto Braga Bianchet. O Satyricon de Petrônio: tradução e estudo lingüístico.

Orientadora: Profa. Dra. Zelia Ladeira Veras de Almeida Cardoso.

s e t e m b r o:

Marcos Martinho dos Santos. Lições sobre alegoria de gramáticos e rétores gregos e latinos.

Orientadora: Profa. Dra. Zelia Ladeira Veras de Almeida Cardoso. 


\section{Dissertações de mestrado (pelo mês de apresentação)}

$\mathrm{m}$ a r ç o:

Renato Ambrósio. A retórica no prólogo dos historiadores latinos.

Orientadora: Profa. Dra. Angélica Chiappetta.

a b r i l:

Clóvis Luiz Alonso Júnior. Reflexões sobre o pronome relativo e a oração adjetiva em latim e português.

Orientador: Prof. Dr. Ariovaldo Augusto Peterlini.

Ricardo da Cunha Lima. Os Paradoxa Stoicorum de Cícero: tradução e estudo.

Orientadora: Profa. Dra. Zelia Ladeira Veras de Almeida Cardoso.

j u n ho:

Rosângela Maria Souza Silva. Considerações sobre o De deo Socratis de Apuleio.

Orientadora: Profa. Dra. Adriane da Silva Duarte.

o u t u b r o:

Viviane Mayumi Ishizuka. Teógnis, a voz de Mégara: kléos, némesis e philía.

Orientadora: Profa. Dra. Paula da Cunha Correa.

\section{Pesquisas em andamento (por linha de pesquisa)}

\section{Narrativa greco-latina}

A selvagem perdição: interpretação da Ilíada.

Doutorando: André Malta Campos. Orientador: Prof. Dr. José Antônio Alves Torrano. 
As Argonáuticas de Apolônio de Rodes: tradução e estudo.

Mestrando: Fernando Rodrigues Júnior.

Orientadora: Profa. Dra. Adriane da Silva Duarte.

As Metamorfoses de Ovídio.

Doutoranda: Elaine Cristina Prado dos Santos.

Orientadora: Profa. Dra. Ingeborg Braren.

Cornelius Nepos e a biografia latina.

Mestrando: Leonardo Davine Dantas.

Orientador: Prof. Dr. Antônio da Silveira Mendonça.

Edição e estudo do manuscrito As transformações de Ovídio.

Mestrando: Aristóteles Angheben Predebon.

Orientador: Prof. Dr. João Angelo Oliva Neto.

Hinos homéricos teogônicos.

Doutoranda: Maria Lúcia Gili Massi.

Orientador: Prof. Dr. Antônio Medina Rodrigues.

Manobras poéticas entre a Ilíada e a Odisséia: o caso de Odisseu.

Doutorando: Christian Werner.

Orientadora: Profa. Dra. Filomena Yoshie Hirata.

O lógos sensivel: a narrativa homérica como experiência da sensibilidade.

Doutorando: Antônio Gomes da Silva.

Orientador: Prof. Dr. Henrique Graciano Murachco.

Os hinos de Calímaco: poesia e poética.

Mestranda: Erika Pereira Nunes.

Orientador: Prof. Dr. Antônio Medina Rodrigues. 
Os hinos homéricos.

Mestrando: Gilmar Pereira da Silva.

Orientador: Prof. Dr. Henrique Graciano Murachco.

Tácito e a nova função da retórica.

Doutorando: Pablo Schwartz Frydman.

Orientadora: Profa. Dra. Ingeborg Braren.

\section{Poesia, lírica, satírica e didática}

A figura de Afrodite no período arcaico.

Doutoranda: Mary Macedo de Camargo Neves Lafer.

Orientadora: Profa. Dra. Filomena Yoshie Hirata.

A formação do gênero bucólico em Virgúlio.

Mestrando: Alexandre Pinheiro Hasegawa.

Orientadora: Profa. Dra. Angélica Chiappetta.

A "Pítica VII" de Píndaro: tradução, anotação e estudo.

Mestrando: Alisson Alexandre de Araújo.

Orientadora: Profa. Dra. Paula da Cunha Correa.

As Astronômicas de Marco Manílio: estudo e tradução.

Mestrando: Marcelo Vieira Fernandes.

Orientadora: Profa. Dra. Ingeborg Braren.

Encantos de uma deusa: fragmentos de Afrodite na lírica de Safo.

Mestranda: Giuliana Ragusa de Faria.

Orientadora: Profa. Dra. Paula da Cunha Correa.

Implicações da métrica nas Odes de Horácio.

Doutoranda: Heloísa Maria Moraes Moreira Penna.

Orientadora: Profa. Dra. Zelia Ladeira Veras de Almeida Cardoso. 
O arcadismo nos Idílios de Teócrito e nas Bucólicas de Virgílio.

Mestrando: Márcio Luiz Moitinha Ribeiro.

Orientadora: Profa. Dra. Zelia Ladeira Veras de Almeida Cardoso.

O "Livro IV" das Elegias de Propércio: lírica e nacionalismo.

Doutorando : Ricardo da Cunha Lima.

Orientadora: Profa. Dra. Zelia Ladeira Veras de Almeida Cardoso.

Estudo e tradução do De satyrica graecorum poesi et romanorum satira libri duo de Isaac Casaubon.

Mestrando: Adriano Scatolin.

Orientadora: Profa. Dra. Zelia Ladeira Veras de Almeida Cardoso.

\section{Teatro greco-latino}

A Assembléia das mulheres de Aristófanes: tradução e estudo.

Mestranda: Tatiana Vieira Barcelos.

Orientadora: Profa. Dra. Adriane da Silva Duarte.

A Ifigênia em Áulis de Eurípedes: introdução, tradução e notas.

Mestrando: Wilson Alves Ribeiro Junior. Orientadora: Profa. Dra. Adriane da Silva Duarte.

A Ifigênia em Táuris de Eurípedes.

Doutorando: Fabricio Possebon.

Orientador: Prof. Dr. José Antônio Alves Torrano.

Aristófanes e Platão: a justiça na pólis.

Doutoranda: Ana Maria César Pompeu.

Orientador: Prof. Dr. José Antônio Alves Torrano. 
Características da comédia de Plauto.

Mestranda: Yara Dias da Silva.

Orientadora: Profa. Dra. Zelia Ladeira Veras de Almeida Cardoso.

Estudo e comentários da Hécuba de Eurípides.

Mestranda: Érica Siani Moraes.

Orientadora: Profa. Dra. Paula da Cunha Correa.

O Hércules no Eta de Sêneca.

Doutorando: José Geraldo Heleno.

Orientadora: Profa. Dra. Zelia Ladeira Veras de Almeida Cardoso.

Metalinguagem e mímesis em Plauto.

Doutoranda: Isabella Tardin Cardoso.

Orientador: Prof. Dr. Antônio da Silveira Mendonça.

Mito e tragédia.

Doutoranda: Lúcia Rocha Ferreira.

Orientador: Prof. Dr. José Antônio Alves Torrano.

Os caminhos da paixão no Hipólito de Eurípides.

Doutorando: Fernando Crepim Zorrer da Silva.

Orientador: Prof. Dr. José Antônio Alves Torrano.

\section{Discurso greco-latino}

A comédia na argumentação do Pro Caelio de Cícero.

Mestrando: Paulo Silva Sampaio.

Orientadora: Profa. Dra. Angélica Chiappetta.

A doutrina da elocução segundo o Orator de Cícero.

Mestrando: Tomislav Deur.

Orientadora: Profa. Dra. Angélica Chiappetta. 
A educação na Antigüidade.

Doutoranda: Marly de Bari Matos.

Orientadora: Profa. Dra. Ingeborg Braren.

A figura feminina nos Moralia de Plutarco: heroísmo e outras virtudes.

Mestranda: Mariana Duarte Silveira.

Orientadora: Profa. Dra. Adriane da Silva Duarte.

A memória na retórica latina.

Mestranda: Elisa Platzeck Leonardi.

Orientadora: Profa. Dra. Angélica Chiappetta.

Advogados de Cristo e falsos mestres. Heresia, intolerância e liberdade de consciência no século XVI: o caso Miguel Servet.

Doutoranda: Elaine Cristine Sartorelli.

Orientadora: Profa. Dra. Ingeborg Braren.

Anotações sobre o texto grego da Epístola de Tiago com ênfase no aspecto verbal, tema e argumentação.

Mestrando: Heitor Bittencourt Filho.

Orientador: Prof. Dr. Henrique Graciano Murachco.

Edição crítica do De oratore de Marcus Tullius Cicero.

Mestranda: Luana dos Santos Castro.

Orientador: Prof. Dr. José Rodrigues Seabra Filho.

Imagens e poder: considerações sobre a representação de Otávio Augusto (44 a.C.-14 d.C.). Doutorando: Paulo Martins.

Orientadora: Profa. Dra. Ingeborg Braren.

O aspecto polêmico do Contra Rufino de Jerônimo.

Doutorando: Luís Carlos Lima Carpinetti.

Orientador: Prof. Dr. Antônio da Silveira Mendonça. 
O prólogo dos diálogos filosóficos de Cícero.

Mestranda: Bernardeth Oliver Guandaligni.

Orientadora: Profa. Dra. Angélica Chiappetta.

O Timeu de Platão.

Mestrando: Kleber Henriques Massi.

Orientador: Prof. Dr. Antônio Medina Rodrigues.

Os Moralia de Plutarco.

Mestranda: Cheila Aparecida Bragadin.

Orientador: Prof. Dr. Henrique Graciano Murachco.

Retórica a Herênio: êthos e páthos.

Mestranda: Adriana Seabra.

Orientadora: Profa. Dra. Angélica Chiappetta.

Retórica a Herênio: fides e auctoritas.

Mestranda: Ana Paula Celestino Faria.

Orientadora: Profa. Dra. Angélica Chiappetta.

O De legibus de Cícero: tradução e estudo.

Mestrando: Marcos da Silva Kucharsky.

Orientadora: Profa. Dra. Zelia Ladeira Veras de Almeida Cardoso.

O Timeu de Platão traduzido por Cícero.

Mestranda: France Yvonne Murachco.

Orientador: Prof. Dr. José Antônio Alves Torrano.

\section{Estrutura da frase grega e latina}

A abordagem comunicativa no ensino do latim.

Mestrando: Sílvio César da Silva.

Orientador: Prof. Dr. José Rodrigues Seabra Filho. 
A doutrina do verbo nos grammatici latini.

Doutorando: José Dejalma Dezotti.

Orientador: Prof. Dr. Ariovaldo Augusto Peterlini.

A interdiscursividade da teologia e do direito penal no campo semântico da língua latina. Mestrando: Jânio Celso Silva Veiga.

Orientador: Prof. Dr. José Rodrigues Seabra Filho.

A onomatopéia na língua latina.

Mestranda: Maria Lucilia Ruy.

Orientador: Prof. Dr. José Rodrigues Seabra Filho.

Morfossintaxe histórica a partir de um texto de Fedro.

Mestrando: Marcelo Ferreira da Silva.

Orientador: Prof. Dr. José Rodrigues Seabra Filho.

O De interpretatione de Aristóteles: um marco na história da língua grega.

Doutorando: Guilherme Mello Barreto Algodoal.

Orientador: Prof. Dr. Henrique Graciano Murachco.

O discurso gramatical antigo, seu reflexo em Quintiliano e sua repercussão: algumas questões.

Doutorando: Marcos Aurélio Pereira.

Orientador: Prof. Dr. Antônio da Silveira Mendonça.

Uma nova aprendizagem do grego do Novo Testamento.

Mestrando: Esequias Soares da Silva.

Orientador: Prof. Dr. Henrique Graciano Murachco. 
Disciplinas de pós-graduação ministradas por Professores Convidados em 2002

Em 2002, dois Professores Convidados colaboraram nas atividades do PPG Letras Clássicas do DLCV/FFLCH/USP, ministrando disciplina de pós-graduação e também participando de reuniões de discussão com os pesquisadores do Programa, a saber: o Prof. Dr. CARlos LÉvy (Université de Paris IV / Sorbonne) e o Prof. Dr. Pierre Judet de La Combe (École Pratique des Hautes Études en Sciences Sociales). A esses professores, mais uma vez, o Programa agradece a colaboração e expressa a honra de os ter tido visitantes. A seguir, resumem-se as disciplinas que cada um ministrou:

\section{1. nome e sigla da disciplina: "La rhétorique stoïcienne" (FLC 5910).}

Professor Convidado: Prof. Dr. Carlos Lévy (Université de Paris IV / Sorbonne)

local: DLCV/FFLCH/USP

período: de 27 de agosto a 11 de setembro de 2002

promoção: PPG Letras Clássicas do DLCV/FFLCH/USP

apoio: FAPESP

\section{1. apresentação da disciplina:}

Em seis aulas, a saber, nos dias 27 e 28 de agosto e nos dias 3, 4, 10 e 11 de setembro, o Prof. Dr. Carlos Lévy ministrou a disciplina de pós-graduação intitulada "La rhétorique stoïcienne", em que tratou a relação entre retórica e filosofia estóica latina e também grega, expondo, entre outros, os seguintes casos: a doutrina retórica dos estóicos Zenão, Cleantes e Crisipo; a crítica de Cícero à retórica estóica; a importância da filosofia para o rétor Frontão, e a importância da retórica para o filósofo Marco Aurélio; as posições de Sêneca o Rétor e Tácito para com as mudanças da eloqüência romana; a preceituação retórica de Sêneca o Filósofo. Tal disciplina é, pois, plenamente afim com linhas e projetos de pesquisa do PPG Letras Clássicas da FFLCH/USP, a saber: a) com a Linha de Pesquisa "Discurso teórico greco-latino"; b) com os Projetos de Pesquisa: "Teorias do discurso na Antigüidade: retórica e poética em Roma" e "Rhetorica ad Herennium: tradução, estudo e comentário"; c) com pesquisas individuais de discentes e docentes; além disso, afina-se com pesquisas desenvolvidas noutros programas similares. Por isso, atraiu muitos pesquisadores, não só do PPG Letras Clássicas da FFLCH/USP, mas do PPG Lingüística do IEL-UNICAMP. 


\section{2. resumo das aulas:}

$1^{\text {a }}$ aula $(27 / 8)$ :

[Acerca das lições dos primeiros estóicos sobre retórica]

- o estoicismo pretende ser um sistema racional perfeito; assim, Catão afirma que do sistema estóico não se pode alterar uma única letra (Cic. Fin. III). Já a retórica estóica, por sua natureza eminentemente prática, pode-se dizer mais romana que grega.

- o sistema estóico surge com Zenão de Cício (332-262 a.C.), que fundou a escola do Pórtico cerca de 300 a.C.. Quanto à aplicação prática da doutrina estóica, Zenão entrevê antes a aplicação ética que a política, de modo que vise antes ao aperfeiçoamento do indivíduo que ao governo da cidade. Teria invertido o arrazoado de Hesíodo, segundo o qual primeiro é o homem que pensa tudo por si, e segundo, o que obedece àquele que pensa e fala bem (Hes. Op. 93-5); pois consideraria a busca individual da verdade menos importante que a capacidade de obedecer ao que detém a verdade.

- considerava-se que os estóicos tinham uma linguagem sóbria, desprovida de retórica; todavia, escreveram vários tratados de retórica: Theophrastus quoque, Aristotelis discipulus, de rhetorice diligenter scripsit, atque hinc uel studiosius philosophi quam rhetores praecipueque Stoicorum ac Peripateticorum princeps (Quint. III 1,15). Primeiro, dividem a filosofia em três, a saber: em física, ética e lógica; depois, subdividem a lógica em duas, a saber: em dialética e retórica. É o que já faz Zenão, na esteira de Xenócrates, que teria sido o primeiro a propor aquela tripartição, comparando a lógica à casca do ovo, e a física, à clara, e a ética, à gema; ou ainda, a lógica, à cerca do jardim, e a física, à terra, e a ética, à árvore. Demais, também a metáfora é procedimento caro aos estóicos; por exemplo, a Zenão, que chamou a sensação polvo.

- Zenão teria criado uma doutrina perfeitamente rigorosa, em que a forma ou retórica se subordinaria ao pensamento ou lógica: cum compresserat digitos pugnumque fecerat dialecticam eiusmodi esse, cum autem deduxerat et manum dilatauerat, palmae illius similem eloquentiam esse dicebat (Cic. Or. 113-4). A dialética é um discurso descontínuo, ou melhor, faz-se por perguntas e respostas, ao passo que a retórica se perfaz num discurso contínuo. Se para Aristóteles a relação entre retórica e dialética respeita ao verossímil, para Zenão, porém, respeitaria ao verdadeiro. Demais, a lógica é, para Zenão, formal, ou melhor, silogística, e a retórica é uma das virtudes do sábio, como também, por exemplo, a coragem. 
- os estóicos consideram a retórica epistéme tô̂ eu légein ou scientia bene dicendi (Quint. II 15,34-5). Ora, para os estóicos, a tékhne seria um sistema de conceitos, elaborado para fins práticos, que são a utilidade para as coisas da vida; já a epistéme seria um saber total, ilimitado, que conheceria o sentido de todos os saberes e, assim, seria o sistema dos sistemas.

- o segundo grande chefe do Pórtico, Crisipo (277-204 a.C.), teria concebido a retórica com tal rigor que, segundo Cícero, ela seria útil a quem quisesse emudecer... Pois Crisipo, fiel ao arrazoado socrático, segundo o qual só fala bem quem pensa bem, se distanciaria maximamente não só dos sofistas, mas de Platão, que ainda visaria à persuasão do ouvinte. Porém, era parecer dele que só o sábio pudesse ser orador e atuar como cidadão para o qual a riqueza, fama e saúde fossem bens verdadeiros. Na verdade, o sábio, embora não considerasse verdadeiros tais valores, adotá-los-ia como tais ao falar aos não sábios. Daí, Crisipo testemunha da tensão entre duas tendências: de um lado, a tendência a pensar e dizer a verdade e, de outro, a tendência a ser útil.

- em 155 a.C., Atenas envia a Roma três filósofos: o acadêmico Carnéades, o estóico Diógenes de Babilônia e o peripatético Critolau: tum admiratione fuisse aiunt Rutilius et Polybius philosophorum trium sui cuiusque generis facundiam uiolenta, incitata@@et rapida Carneades dicebat, scita et teretia Critolaus, modesta Diogenis et sobria (Gell. VI 14,10). Assim, Diógenes, por sua eloqüência modesta e sóbria, testemunharia da impossibilidade de dissociar retórica e filosofia; Panécio, porém, tentou adaptar a eloqüência à vida romana: iudicis est semper in causis uerum sequi, patroni nonnumquam uerisimile, etiam si nimis sit uerum, defendere, quod scribere [...] non auderem, nisi idem placeret grauissimo Stoicorum Panaetio (Cic. Off. II 5). Assim, associou-se o estoicismo ao mos maiorum, segundo o qual o indivíduo devia submeter-se à natureza e sacrificar-se em nome da res publica e ter por valor supremo a retidão moral.

- Posidônio recorria a hipérboles e várias figuras, de modo que falava com facúndia (cf. Sen. Ep. 90,2: facunde) e disputava gravemente e copiosamente (cf. Cic. De or. II 61: grauiter et copiose disputauisse). Ao passo que Hermágoras divide a retórica em hipótese e tese, Posidônio divide-a em voz e caso: In duo et Posidonius [status] diuidit uocem et res. In uoce [quam] putat an significet quid, quam multa, quo modo rebus coniecturam, quod uocat kat' aísthesin et qualitatem et finitionem, cui nomen dat kat' énnoian (QuiNT. III 6,37). Em muitos pontos, porém, os tratados estóicos de retórica comungavam com os demais; por exemplo, na divisão da retórica em deliberativa, judicial e epidíctica; ou ainda, em invenção, elocução, disposição e ação, embora aqui não fizessem entrar a memória. 
- em suma, Roma recebe dos estóicos uma pluralidade de lições, de modo a adaptálas à sua realidade, ou ainda, harmoniza a racionalidade do sistema estóico com a racionalidade do mundo romano. Uma só coisa tem valor absoluto: a retidão moral.

\section{$2^{\text {a }}$ aula $(28 / 8)$ :}

- ao referir a retórica estóica, Plutarco emprega tékhne, e não epistéme, e diz que o orador tem de cuidar dos movimentos das mãos e das expressões faciais (Plut. M. 1047 a). Porém, diz que o orador não tem de cuidar das elipses e solecismos, mas tão-só do béltion, isto é, da verdade. Ora, tal orientação é própria do estoicismo, que, ademais, a introduz em Roma (id. ib. 1047 a-b).

- Quintiliano pergunta se a retórica é das artes médias, que, por si, não são louváveis nem censuráveis, mas dependem apenas dos que as empregam, ou se é uirtus (Quint. II 20,1). Pois, se é arte média, depende apenas dos que dela usam, se, porém, é virtude, basta-lhe a verdade. Ora, os estóicos consideram a retórica um aspecto da sabedoria e da virtude (id. II 20,6). A propósito, diz Goldshmidt que o sistema estóico considera a circularidade, ou melhor, a passagem do mesmo ao mesmo (Goldshmidt, Le système stoïcien et l'idée de temps); porém, aquilo de que se parte é dado pela natureza, e aquilo a que se torna é conquistado pela razão, o que equivale a dizer que a natureza nos dá a potência de justiça, mas que é só depois da alcançar esta pela razão que a justiça se faz plena. Assim, se conquistamos a retórica pela razão, ela torna-se uma virtude; se, porém, nos detemos no meio do processo, ela permanece uma arte.

\section{[Acerca da reação dos romanos à chegada do estoicismo]}

- Catão o Censor é uma figura complexa. Embora seja o defensor do mos maiorum e adversário da helenização dos costumes romanos, leva a Roma o poeta Ênio, que é helenizante; também foi o primeiro romano a publicar os próprios escritos. Ora, alguns fragmentos atribuídos a Catão bem serviriam a um estóico qualquer, por exemplo: rem tene, uerba sequentur (frg. Jordan 15); uir bonus, dicendi peritus (frg. Jordan 14).

- segundo Cícero, dos dois epítetos de Júpiter, a saber: optimus e maximus, o primeiro é muito superior ao segundo; pois optimus equivale a beneficentissimus. Tal lição, estóica, significa que, melhor que ser virtuoso, é transmitir a virtude a outrem (CIc. Nat. II 65). 
- é curiosa a introdução do estoicismo em Roma, e sobretudo a introdução da retórica estóica, porque, ao passo que Panécio abrandara o rigor desta para adaptála aos costumes romanos, os rétores romanos, todavia, recusaram aquela forma abrandada, por preferir a esta a original, de Zenão de Cício e Crisipo de Soles. De Panécio diz Cícero: eius omnis in dicendo facultas in historia ipsius non inelegante scripta perspici potest, quae neque nimis est infans neque perfecte diserta (Cic. Br. 101). De outros, diz: Traducti a disputando ad dicendum inopes reperiuntur. Vnum excipio Catonem in quo perfectissimo Stoico summam eloquentiam non desiderarem, quam exiguam in Fannio, ne in Rutilio quidem magnam, in Tuberone nullam uideo fuisse (id. ib. 118). Ora, Tuberão era congruens cum ea disciplina quam colebat, paulo etiam durior (id. ib. 17). Assim, os discípulos de Panécio, em vez de praticar o estoicismo edulcorado daquele, praticavam o severo de Zenão. Assim também, Rutílio praticava o estoicismo, ainda que discípulo de Panécio.

- com Q. Múcio Escévola (117 a.C.) começa o conflito entre o direito romano e a ética estóica. Pois, em vez de fazer-se discípulo de Panécio, fez-se discípulo de Blasso de Cumas; porém, houve um acordo muito harmonioso entre o direito romano e a ética estóica. Ora, lê-se em Cícero: haec iura ciuilia quae iam pridem in nostra familia sine ulla eloquentiae laude uersantur (Cic. De or. I 39); pois o direito não necessita eloqüência, mas deve tão-só permitir aos homens entendê-lo com o pensamento. Porém, na causa curiana, Q. Múcio Escévola, o maior conhecedor de direito, perde o embate para Crasso, o mais hábil em eloqüência.

\section{[Acerca da agudeza dos estóicos]}

- segundo G. Moreta (1995), a expressão ciceroniana mais importante aplicada aos estóicos é: acutissimum et subtilissimum dicendi genus (Cic. De or. II 98; Br. 202). Ora, o que Cícero repreende aos estóicos é, não a agudeza, mas certa agudeza autodestrutiva, porque obscura: ad extremum ipsi se compungunt suis acuminibus (id. De or. II 158). Demais, Cícero opõe os estóicos a Aristóteles, que diz possuir acies mentis e ver rerum omnium uim naturamque (id. ib. II 160); em outras palavras, a agudeza de Aristóteles consiste em ver claramente a natureza das coisas, e a dos estóicos, em enredar as coisas em seus raciocínios e, assim, obscurecê-las. É verdade que Catão pondera que a obscuridade está nas coisas, mas Cícero retruca, dizendo que a obscuridade está, não nas coisas, mas nas palavras (id. Fin. IV 2). 


\section{[Acerca do uso das figuras]}

- mais que tudo, o que Cícero reclama dos estóicos são as figuras. Ora, uma das expressões com que as designa é lumina; daí, se os estóicos carecem de figuras, a eloqüência deles é obscura.

- Cícero, ao dizer: fateor me oratorem, si modo sim, aut etiam quicumque sim, non ex rhetorum officiis, sed ex Academicis his spatiis exstitisse (Cic. Or. 12), refere-se a Filão de Larissa, que foi a Roma em 88 a.C. ensinar tanto filosofia quanto retórica. Demais, o mesmo Cícero vai a Atenas em 78 a.C. seguir as lições de Antíoco de Áscalo; mas não há testemunho de que este tenha ensinado retórica. Seja como for, a expressão com que Cícero resume o legado que herdou da Academia é: ubertas et quasi silua dicendi (id. ib.), de que silua dicendi refere a matéria filosófica tripartite, isto é, constituída de lógica, física e ética. Porém, diz Cícero que à matéria filosófica devem acrescentar-se os ornamentos: ad has tot tantasque res adhibenda sunt ornamenta innumerabilia. Ora, segundo os estóicos, o lógos, ativo, fecunda a hýle, passiva; Cícero, pois, acaba por propor que esta fecunde aquele.

\section{$3^{\mathrm{a}}$ aula $(3 / 9)$ :}

- a julgar por Diógenes de Laertes, os estóicos chegaram a propor conceitos novos de retórica, mas conservaram-lhe as categorias fundamentais, a saber: $1^{\circ}$ as eloqüências deliberativa, judicial e encomiástica; $2^{\circ}$ invenção, elocução, disposição e ação; a memória, porém, não é mencionada por Diógenes de Laertes; $3^{\circ}$ prólogo, narração, refutação e epílogo; a confirmação, porém, não é mencionada por Diógenes de Laertes (DL VII 42). Também definições conservaram; por exemplo, a de parádeigma, que se lê num tratado de retórica anônimo: parádeigma estì genoménou prágmatos apomnemóneusis eis omoíosin@@ toûnûn zdetouménou (RG I 447).

- Zenão teria empregado as quatro categorias de Teofrasto, acrescentando-lhes, contudo, uma quinta, a xyntomía. Mas há dificuldades. Pois a primeira categoria é o helenismo; porém, os estóicos cuidam apenas do rigor da invenção, e aceitam mesmo falhas de elocução tais como solecismos. Assim também, a segunda categoria é a saphéneia; porém, os estóicos não perseguem as flores da elocução (cf. Cic. Par.: nullum sequitur florem orationis). Por outro lado, o conceito de saphéneia supõe o de enárgeia, que é tanto retórico como filosófico. Assim também, a terceira categoria é o prépon, isto é, aquilo que é adaptado ao ouvinte e ao caso; porém, o estóico pretende ser livre de tal contingência, ou melhor, pretende ser adequado 
antes à verdade que ao ouvinte. Assim também, a quarta virtude é a kataskeué, isto é, o aspecto das figuras (cf. DL VII 59: kataskeuè dè estì léxis ekpephyguià@@@ tò idiotismón). Enfim, a xyntomía é a inovação estóica de Diógenes de Babilônia, que a define como pròs délosin toû prágmatos, de modo a equiparar, como costumam os estóicos, mostrar (cf. délosin) e demonstrar.

\section{[Acerca de Cícero e os estóicos]}

- segundo Aristóteles, o orador deve guardar para si o éndoxon e encerrar o adversário no parádoxon (ARstT. Ref. soph. XII 172 b 25); os estóicos, porém, invertem a estratégia aristotélica, porque pretendem enunciar as coisas do ponto de vista da sabedoria, que colide com a dóxa. Ora, é justamente a harmonizar os pontos de vista aristotélico e estóico que Cícero visa nos Paradoxos dos estóicos. Já no Por Murena, Cícero perfaz um paradoxo; pois, ao pretender corrigir Catão, propõe-se curvá-lo, e não endireitá-lo (Cic. Mur. 60). Pois, conforme afirma, a natureza forjou Catão para a virtude, mas o que põe isso a perder é o excessivo rigor de Catão; em outras palavras, a doutrina estóica é tão rigorosa que diverge da natureza. $\mathrm{Na}$ verdade, se os estóicos pretendem que natureza e doutrina sejam igualmente racionais, Cícero, contudo, interpõe-lhes um hiato, de modo a mostrar que a doutrina estóica não é espelho da natureza. Mas alguns argumentos de Cícero são capciosos. Pois, quando diz que, para os estóicos, todo crime é igualmente nefasto, de modo que não distingam o crime de sufocar um galo e o crime de estrangular o próprio pai (id. ib. 61), desconsidera o preceito estóico, segundo o qual a injustiça só pode ser cometida contra um animal racional. Além disso, Cícero altera a elocução ao passar da exposição dos preceitos estóicos às dos preceitos de Platão e Aristóteles, assim: lá, usa tão-só de frases curtas e justapostas; aqui, usa de frases longas e circulares (cf. id. ib. 62-3). Já no Bruto, que é um tratado, e não um discurso, como o Por Murena, a estratégia de Cícero é outra. Assim, em Mur., diz que a natureza de Catão era boa, mas foi distorcida pela doutrina; em $\mathrm{Br}$., diz que a natureza de Rutílio era rígida e dura, e por isso ele adotou a doutrina estóica.

- Pierre Hadot (P. Hadot, Marc Aurèle: la citadèle intérieure), vale-se do termo cristão de Inácio de Loyola: exercices spirituels, para nomear o diálogo de alguém consigo mesmo, tal e qual praticado por Marco Aurélio e Epicteto. Hadot e Foucault (M. Foucault, Le souci de soi) concordam em que, para os antigos, salvo Aristóteles, o conhecimento das coisas depende do conhecimento de si, ou melhor, o homem só pode conhecer as coisas se se transforma eticamente; por isso, aliás, consideram Descartes o inventor da Modernidade, porque propôs um modo de co- 
nhecimento das coisas que não repousasse na transformação do homem. Porém, Hadot e Foucault parecem considerar o estoicismo a partir de Sêneca, desconsiderando a importância de Cícero para a transformação do estoicismo. Ora, Cícero menciona o principatus penes ipsum aos 30 de janeiro de 45 a.C., bem quando César se apodera do principatus ciuitatis (CIc. Att. XIII 9,4). Ora, seguem-se ao Fin. as Tusc., diálogo entre Cícero e uma personagem anônima e quase muda. Ao passo que Cícero, no "Livro V" do Fin., rememora a época em que ele e outros freqüentaram a Academia, em Atenas, em 68 a.C., nas Tusc., todavia, considera a "Academia de Túsculo", de maneira que, se naquela fora discípulo, nesta é mestre. Ora, segundo Douglas (A. E. Douglas, Form and content in the Tusculan disputations. Cicero the philosopher), Cícero não distingue bem entre disputatio, schola, dialogus; seja como for, disputatio seria uma conferência feita na presença de um interlocutor que intervém raramente, apenas para que a conferência não se transforme em monólogo. Assim, as Tusc. difeririam dos diálogos acadêmicos tais como o Fin., na medida em que são o primeiro diálogo de Cícero em que o interlocutor é anônimo. Mais que isso, porém, Cícero diz àquele interlocutor: reminescere, quoniam initiatus es, quae tradantur in mysteriis (Cic. Tusc. I 29); de fato, Cícero reitera, nas Leis, que fora iniciado nos mistérios de Elêusis com aquele interlocutor (id. Leg. I 38). O interlocutor seria, pois, ou Ático ou um incógnito ou o próprio Cícero. Que fosse Ático é pouco provável, porque Cícero sempre o apresenta como alguém próhelenista e amante do epicurismo. Assim, poder-se-ia supor que as Tusc. fossem um diálogo de Cícero consigo mesmo. De fato, o que diz em Tusc. IV 59: simulas enim quaerere te de sapiente, quaeris fortasse de te, seria como um lapso. Seja como for, nas Tusc., Cícero passaria, segundo Moraux (P. Moraux, La joute dialectique dans le $8^{\mathrm{e}}$ livre des Topiques), do diálogo socrático, em que se tem a impressão da vida e a elaboração do informal, à disputatio posterior, mais rígida. Na verdade, assim como as declamações do jovem Cícero são retóricas, assim se poderia dizer que a declamação do velho Cícero é um exercice spirituel, ou melhor, uma preparação para a morte: ut antea declamitabam causas, quod nemo me diutius fecit, sic haec mihi nunc senilis est declamatio (Cic. Tusc. I 7). Por isso, enfim, o interlocutor de Cícero tinha de ser anônimo, porque Cícero, devendo mudar-se a si mesmo, devia desdobrar-se noutra personagem com a qual dialogasse. Demais, segundo Griffin (M. Griffin, Seneca, a philosopher), é ato por assim dizer simbólico, na época imperial, a ruptura da filosofia com a retórica; ou melhor, Sêneca e Marco Aurélio, embora muito se valham da retórica, devem simbolicamente proclamar divórcio com esta. Se naqueles, porém, há a presença imediata do eu que informa o leitor do esforço do autor para melhorar-se, em Cícero, contudo, oculta-se o eu, prova- 
velmente porque, na república, o pudor manda obriga o autor a ser reticente quando fala de si.

\section{[Acerca de Sêneca o Filósofo]}

- Quintiliano escreveu um texto, hoje perdido, chamado De causis corruptae eloquentiae, em que se supõe que Sêneca figurasse como exemplo da eloqüência fácil e corrupta. De fato, Quintiliano cuida de impedir que Sêneca seja considerado exemplo de boa eloqüência; o mesmo Sêneca, porém, previra que poderia tornar-se um tal exemplo (Sen. Ep. 20). Ora, Quintiliano repreende Sêneca porque este, por sua vez, repreendera autores que aquele considerava superiores, por exemplo, Cícero (id. ib. 108,32-4). Na verdade, Quintiliano admite que Sêneca tivesse aptidão para a eloqüência, mas desaprova-lhe a facilidade da eloqüência e a falta de rigor.

- Sêneca narra os primórdios da humanidade de acordo com Posidônio (id. ib. 90): no princípio, todos os homens eram sábios (id. ib. 90,5); na verdade, os homens primitivos não eram bem sábios, mas imagem da sabedoria (id. ib. 90,11-3); não eram sábios, mesmo quando faziam o que devem fazer os sábios (id. ib. 90,36); eram inocentes por ignorância das coisas (id. ib. 90,46). A narração, pois, obedece à circularidade recorrente do sistema estóico.

- Sêneca ilustra três categorias de proficientes, isto é, de homens que estão a caminho da sabedoria (id. ib. 75): $1^{\text {a }}$ a dos que escaparam às enfermidades da alma, mas a que falta o discernimento claro do estado de alma; $2^{\text {a }}$ a dos que escaparam a grandes enfermidades da alma; $3^{\mathrm{a}}$ a dos que escaparam a certos vícios, mas não a todos.

- Sêneca compara o sábio ao mundo (id. ib. 9). Ora, segundo os estóicos, o mundo permanece entre dois pólos, a saber: a ekpýrosis, em que o mundo é consumido pelas chamas, e o lógos se recolhe em sua natureza ígnea, e a diakósmesis, em que o fogo se dilata, de modo a transformar-se em ar, água e terra e, assim, organizar o mundo.

\section{$4^{\mathrm{a}}$ aula (4/9):}

- Sen. Ep. 12: Sêneca repara, primeiro, nas pedras (cf. 12,1: saxa); depois, nas folhas e troncos (cf. 12,2: frondes; ib.: rami; ib.: trunci); enfim, em Feliciano, que fora vitelo (cf. ib.: 12,3: uetulus) e, agora, é ser falante (12,3). Assim, percorre a 
scala naturae, estabelecida por Aristóteles e muito celebrada pelos estóicos. Demais, trata a circularidade do tempo $(12,4-11)$, ou melhor, os círculos da vida toda, do ano, do mês e do dia, todos delimitados por um começo e um fim $(12,6)$. É possível que tais círculos, concêntricos, compusessem um cone; ora, Crisipo teria solucionado a aporia do cone formulada por Demócrito, segundo o qual dois cortes feitos num cone nem podem ser iguais, porque, assim, o sólido seria cilindro, e não cone, nem podem ser diferentes, porque, assim, o cone seria composto por degraus (Plut. Par. stoic.). Ora, também a sociedade os estóicos dispõem em círculos concêntricos, que são estes: $1^{\circ}$ pai e filho, $2^{\circ}$ família, $3^{\circ}$ cidade, $4^{\circ}$ país, $5^{\circ}$ cosmópolis, que se confunde com a humanidade, de maneira que o afeto que une pai e filho no centro ou topo do cone seja o mesmo que une sábio e humanidade na periferia ou base.

- a eloqüência estóica romana identifica-se, antes de tudo, pela sonoridade, ou melhor, pelo ritmo das sententiae. O fundamento da sentença talvez seja o entimema de Aristóteles, que parte de premissas que são verdadeiras, mas incompletas, isto é, são atelès syllogismós. Na retórica pós-aristotélica, define-se o enthýmema gnomikón como máxima que conclui uma demonstração silogística; por exemplo:@@@à enthymémata onómastai, è hóti ho rhétor autòs autà héureke kaì enthymeîtai è hóti prosenthymeîsthai toîs dikastaîs, ei ti elleípoi, kataleípei (RG I 343,4-6). Daí, aquele que ouve o entimema é obrigado a completar o arrazoado (cf. Quint. VIII 5). Ora, a sentença ainda é rara em Cícero, mas já é mais freqüente em Sêneca o Rétor. - Aristóteles, na Poética, define metáfora como transferência katà tò análogon (ARSTT. Poet. 1457 b 6-9) e, na Retórica, define imagens como metaphoraì lógou deómenai (id. Rhet. III 1407 a); daí, poder-se-ia concluir que estas são uma forma imperfeita daquela. Teriam sido os filósofos da época imperial os responsáveis pelo emprego da imagem na demonstração em detrimento do emprego da metáfora:

imagines quibus ei qui nos uti uetat, neminem mihi uidetur ex antiquis legisse, Posidonius non tantum ad praeceptionem sed etiam suasionem et consolationem et exhornationem necessariam indicat (SEN. Ep. 95,65); [parabolas] quas existimo necessarias [...] ut imbecillitati nostrae adminicula sunt (id. ib. 59,67);: ad haec uerba demonstrandae rei causa descendimus (Ben. IV 12,1).

- é verdade que em Platão o mito intervém, assim como em Sêneca, a sentença; pois um e outro recorrem ao mito e sentença quandode algo não encontram a demonstração racional. Por exemplo, no início do Timeu de Platão, a personagem 
confessa que não é capaz de expor racionalmente criação do mundo e que, por isso, proporá um mythos eikótos. Porém, se, em Platão, o uso do mito se justifica pela debilidade da razão, que não é capaz de compreender certas coisas, em Sêneca, todavia, não há tal justifica, porque Sêneca, estóico, considera as coisas mesmas racionais.

- Sêneca adverte Lucílio de que não é para ocupar-se demasiado com a escritura (SEN. Ep. 75,3). Porém, quando é que nos ocupamos demasiado? Demais, apregoa que a escritura mostre a coisa mais que a si mesma: $[u t]$ res potius quam se ostendat. Assim, defende a superioridade da res sobre os uerba e acresce que a eloqüência deve ser como sombra que segue o filósofo sem que este a perceba (id. ib. 100). Supõe que basta curarse os vícios da alma para que desapareçam os vícios da elocução (id. ib. 114).

- em suma, a teoria senequiana do discurso oscilaria entre dois pólos. Pois, de um lado, nas "Epístolas 100 e 114", Sêneca não deixa lugar à autonomia da eloqüência, que manda submeter-se inteiramente à filosofia; de outro lado, na "Epístola 95", admite o uso das imagens. De fato, de tal oscilação ou tensão testemunham Ep. 40 e Ep. 100,7. Por exemplo, em Ep. 40, Sêneca qualifica a oração de Cícero como oratio pressa, non audax, o que seria contraditório, na medida em que Cícero, que tem oração ampla e abundante e, justamente por isso, nunca é tomado como modelo por Sêneca, é eleito por este como modelo e, ao mesmo tempo, restringido a certo controle.

$5^{\mathrm{a}}$ aula (10/9):

\section{[Acerca de Sêneca o Rétor]}

- a mudança das declamationes para a eloqüência corrupta foi uma mudança de color. Ora, de Cícero a Sêneca o color passou ao centro da inuentio, de modo a determinar o modo de manusear o virtual. Assim, dá-se ao jovem orador um tema imaginário e, às vezes, extravagante, e aquele escolhe o color que aplicará à declamação. Por exemplo, em Sen. Contr. II 34, o tema é o de um escravo acusado de adultério; ora, como o fato fosse comprovado, carecia de algum color: opus erat aliquo colore cum in cubiculo uisa esset cum seruo et marito.

\section{[Acerca de Tácito, Diálogo dos oradores]}

- os discursos do Diálogo dos oradores de Tácito aproximam-se muito da declamatio; por exemplo, os discursos de Messala permitem supor que não foram atuados no 
fórum, mas que se escreveram no escritório: ullo modo ad ueritatem accedentibus controuersiis (TAC. Dial. 31).

- o que é curioso e que, até agora, não foi observado pelos especialistas, é que o color de Sêneca o Rétor não se depara no discurso de Messala. Ora, este considera a decadência da eloqüência romana de acordo com a doutrina do Do orador de Cícero em que se diz que o orador deve ter um saber enciclopédico e deve ser capaz de traduzir teoria em prática. Messala, contudo, não explica a causa de tal decadência; o que, porém, mudou de Cícero para Messala foi a política, ou melhor, encerrou-se a república.

- a disputatio in utramque partem supõe que, embora se possam defender duas teses contrárias, o orador expõe, em segundo lugar, a que lhe parece mais importante ou provável (cf. Cic. Att. II 3,3). Ora, quando se diz, no Diálogo dos oradores, que Carnéades disputou, primeiro, em favor da justiça e, depois, contra a justiça (TAC. Dial. 26), infere-se que fosse contrário à justiça. Já no Da república de Cícero, Filão, primeiro, disputa contra a justiça, e Célio, depois, em favor da justiça; mas Escipião, enfim, tenta harmonizar as duas teses (Cic. Rsp. III).

- Cícero estabelece um lugar-comum, segundo o qual a eloqüência deve acompanhar a ética; no entanto, Materno diz que, em seu tempo, a eloqüência decaiu justamente porque a sociedade está bem. Ora, a dicotomia de retórica e ética parece ser o caso principal de todo o proêmio do Diálogo dos oradores. A propósito, os dois discursos de Materno são contraditórios, pois, no primeiro, diz que a retórica em nada pode contribuir para a vida do orador; no segundo, pondera. - ao passo que Sêneca o Rétor, porque admite o color, compactua com a eloqüência dita decadente, Tácito, contudo, opõe-se a ela. Demais, pondera que não é bem correto dizer que a eloqüência decaiu, porque não é realidade autônoma, e o que decaiu foi o rigor moral, encarnado por Catão, que, todavia, não cuidava da eloqüência. Desse modo, Tácito trata a eloqüência, de modo a demonstrar que o mais importante para a eloqüência está fora desta.

\section{$6^{a}$ aula (11/9):}

\section{[Acerca da relação entre poesia e alegoria]}

- a alegoria foi empregada pelos estóicos como método exegético de ler poesia. Eles não foram os inventores de tal método, mas os aperfeiçoadores. 
- segundo Steinnetz (P. Steinnetz, Allegorische Deutung und allegorische Dichtung in der Alten Stöa), quem primeiro promoveu a alegoria entre os estóicos foi Cleantes de Asso. Long, porém, distingue entre o sentido forte e o sentido fraco da alegoria. Aquele aplica-se ao texto cujo autor espera ser interpretado alegoricamente, por exemplo, à Divina Comédia de Dante. O sentido fraco aplica-se ao texto que permite a interpretação alegórica, ainda que o autor não tenha previsto tal interpretação, por exemplo, à Ilíada e Odisséia. Demais, o problema da alegoria de sentido fraco consiste em saber se os que a descobrem a consideram realmente fraca; por exemplo, é para saber se os estóicos, quando interpretam Homero alegoricamente, consideram que o Poeta de fato escreveu alegoricamente, ou não. Em outras palavras, o problema consiste em saber, não o que Homero subentendeu em seus poemas, mas o que os estóicos entendem que ele teria subentendido.

- segundo Steinnetz, o método de Cleantes interpretar Homero teria sido mais filológico que filosófico. No Da natureza dos deuses de Cícero, o adversário epicureu diz que Zenão de Cício destrói as doutrinas usuais e recebidas dos deuses ao considerar que os nomes destes ocultam a física estóica (Cic. Nat. I 36). Por exemplo, Homero deriva a palavra kháos de khéesthai; ora, de acordo com a física estóica, tal é a constituição do mundo: que o fogo se faça ar, e este, água, e esta, terra; daí, o caos seria o momento em que a água é vertida (cf. khéesthai), de modo a transformar-se em terra. Assim também, Crisipo vale-se de Homero como de testemunha do dogma estóico segundo o qual tudo é dominado pelo destino.

- seja como for, os estóicos consideram, em geral, que os poetas antigos teriam vislumbrado verdades que não puderam descrever corretamente, mas que foram formuladas sistematicamente pela filosofia estóica. Repare-se, a propósito, nesta frase do adversário epicureu do Da natureza dos deuses de Cícero: ut iam ueterrimi poetae qui, haec ne suspicati quidem sint, Stoici fuisse uideantur (id. ib. I 39-40). Ora, se se interpreta o $u t$ como consecutivo, Homero faz-se estóico por decorrência da exegese estóica; se, porém, se interpreta como final, à maneira de Long, os estóicos teriam tido a intenção de fazer de Homero um estóico.

- segundo o Da língua latina de Varrão e o Da dialética de Agostinho, os estóicos consideram que a realidade imprime sua marca na linguagem, que a reproduziria mimeticamente; por exemplo, a palavra hinnitus, segundo Agostinho. Assim, os estóicos creriam que os poetas antigos teriam exprimido verdades em seus poemas porque a linguagem mesma mimetiza aquelas. Por isso, enfim, a importância da etimologia para a exegese estóica da poesia. 


\section{[Acerca da relação entre poesia e filosofia]}

- antes de tudo, a relação entre poesia e filosofia explica-se porque, no mundo antigo, a expressão filosófica foi, a princípio, poética.

- Ênio foi filósofo e, embora tenha bebido os ensinamentos gregos, modificou-os, de modo a conciliar coisas gregas e romanas muito distantes umas das outras; por exemplo, embora aceite a metempsicose no início dos Anais, admite uma doutrina incompatível com o pitagorismo, que é a permanência de um simulacro do corpo após a morte. $\mathrm{Na}$ verdade, Ênio não pretende desenvolver todos os sistemas filosóficos gregos, mas recolhe doutrinas várias para dar aos romanos uma sinopse da filosofia grega; pois os primeiros romanos que escreveram sobre filosofia assumiram o papel de educadores. No Evêmero, de que alguns passos são recolhidos por Lactâncio, expõe as fábulas gregas de acordo com a teologia romana.

- Lucílio, de um lado, transforma o antigo rito funerário etrusco, de que participaria o demônio Persu ( $>$ lat.persona), em gênero satírico; de outro lado, depende do estoicismo de Panécio. Figura ridícula das sátiras de Lucílio é Albúcio, de um lado, porque é demasiado helenizante e, de outro lado, porque é epicureu. Os elementos acadêmicos de Lucílio são muito difusos: $1^{\circ}$ menção de Carnéades; $2^{\circ}$ crítica das aparências; $3^{\circ}$ crítica das crenças religiosas (cf. Cic. Nat. III). Embora a cosmópole estóica não exista para Lucílio, este preserva a organização circular constituída dos círculos concêntricos da pátria, dos parentes e do indivíduo.

- Horácio relaciona Lucílio com a comédia antiga de Aristófanes e outros, de modo a relacioná-lo com uma tradição em que ele mesmo não se filia (HoR. S. I 4,1-8). Ora, apesar de recorrer os lugares-comuns epicureus e estóicos, Horácio foi a Atenas estudar na Academia; de fato, refere, nas Odes, as Socraticae chartae e a Socratica domus. Seja como for, em Hor. S. II 3, o estóico Estertínio pretende converter Damasipo, e este, a Horácio; demais, Estertínio pretende converter Damasipo bem quando este, desesperado, se prepara para lançar-se no rio e morrer. Ora, também Zenão, como reza a lenda, descobriu a filosofia estóica quando, náufrago, chegou a Atenas sem sua embarcação e mercadorias. Tal é, pois, a ironia: que os estóicos só descobrem sua vocação bem quando já perderam todas as esperanças... Nos últimos versos, porém, lê-se: $O$ maior tandem parcas, insane, minori, em que a graça supõe uma gradação da loucura (cf. maior e minori) que é de todo estranha ao sistema estóico.

MARCOS MARTINHO DOS SANTOS

Faculdade de Filosofia, Letras e Ciências Humanas Universidade de São Paulo 
2. nome e sigla da disciplina: "Vers une interprétation de la tragédie grecque. Philologie, histoire, philosophie" (FLC 5911).

Professor Convidado: Prof. Dr. Pierre Judet de La Combe (École Pratique des Hautes Études en Sciences Sociales).

local: DLCV/FFLCH/USP

período: de 10 a 25 de setembro de 2002

promoção: PPG Letras Clássicas do DLCV/FFLCH/USP apoio: FAPESP

\section{1. apresentação da disciplina:}

Em seis aulas, a saber, nos dias 10, 11, 17, 18, 24 e 25 de setembro, o Prof. Dr. P. Judet de La Combe ministrou a disciplina de pós-graduação intitulada "Vers une interprétation de la tragédie grecque. Philologie, histoire, philosophie", em que apresentou e discutiu os diferentes níveis de interpretação do teatro grego, desde o estabelecimento e decifração da letra dos textos até a reconstituição das coerências semânticas e a discussão dos modelos interpretativos existentes, alternando a análise filológica precisa e a discussão teórica e histórica dos pressupostos da disciplina. Tal disciplina é, pois, plenamente afim com linhas e projetos de pesquisa do PPG Letras Clássicas do DLCV/FFLCH/USP, a saber: a) com a Linha de Pesquisa "Teatro greco-latino"; b) com os projetos de pesquisa "Aspectos da comédia clássica", "As tragédias de Ésquilo: tradução e estudo", "Eurípides: o poeta e a cidade" e "O teatro de Sófocles"; c) com projetos individuais de pesquisa de dioscentes e docentes; c) com pesquisas individuais de discentes e docentes; além disso, afina-se com pesquisas desenvolvidas noutros programas similares. Por isso, atraiu muitos pesquisadores, não só do PPG Letras Clássicas da FFLCH/USP, mas do PPG Lingüística do IEL-UNICAMP e do Grupo de Estudos Clássicos do NEFIH do Departamento de Filosofia da Faculdade de Artes, Filosofia e Ciências Sociais (FAFCS) da Universidade Federal de Uberlândia (UFU).

\section{2. resumo das aulas:}

\section{$1^{\mathrm{a}}$ aula $(10 / 9)$ :}

- em vez de uma disciplina temática de teatro grego, propõe-se uma disciplina metódica de filologia clássica aplicada ao teatro grego. Ora, os hermeneutas dos 
textos antigos podem-se repartir assim: $1^{\circ}$ políticos (como V. Citti; V. di Benedetto; D. Lanza), para os quais o poeta antigo, ao compor um texto, realiza uma práxis ou ação; $2^{\circ}$ político-antropológicos (como J.-P. Vernant; N. Loraux), que não são filólogos, não se interessam pela crítica textual, mas tão-só pelas categorias antropológicas, de que o poeta antigo seria porta-voz, ainda que inconsciente; $3^{\circ}$ poéticos (como J. Bollack), para o qual o poeta antigo, ao compor um texto, faz uma reflexão sobre a poesia; $4^{\circ}$ filosóficos ou desconstrutivistas (como J. Derrida; P. Pucci; S. Goldhill), que não se interessam pelas categorias políticas ou antropológicas, nem pela estruturação poética do texto, mas tão-só pela linguagem, de maneira que admitam que o signo lingüístico é sempre ambíguo e diz sempre mais do que dizemos.

\section{[Comentários aos itens do programa da disciplina]}

\section{1 .}

- o tema da $1^{\text {a }}$ aula é a individualidade da obra de Ésquilo. Ora, segundo P. Szondi, os textos são como indivíduos, e não como exemplos (cf. Szondi, P. Sur la connaissance philologique).

\section{3 .}

- Schleiermacher foi, antes de tudo, filósofo, eclipsado, todavia, por Hegel. Sua obra filológica, porém, foi preservada, primeiro por Dilthey (séc. XIX-XX), e depois por Gadamer (séc. XX). Segundo a máxima inferior deste, os intérpretes só recorrem à ciência hermenêutica quando deparam alguma contradição no texto; por exemplo, quando, no fim do 'Canto I' da Odisséia, se diz que todos os deuses dormem, e, no início do 'Canto II', que Zeus não dorme, contradição que demanda explicação. Segundo a máxima superior, porém, mesmo o que nos parece coerente pode iludir-nos, por esconder, às vezes, alguma relação mais complexa sob a aparência da simplicidade.

- Schleiermacher foi discípulo de Kant e leu as antinomias deste, de maneira que opõe à liberdade a necessidade que impera sobre o escritor. Assim também, Heidegger declara que, quando Hölderlin fala, não é este que fala alemão, mas é a língua alemã que fala por meio do Poeta.

2.

- Aesch. Pers. 1: o verso é enigmático. Há dificuldade sintática no genitivo Persôn tôn oixoménon, pois, em Homero, oixómenos pode significar "os que partiram" e, 
daí, "os que morreram". Seja como for, uma antítese repousa sobre oixoménon, a última palavra do verso, e táde ou "aqui", a primeira.

- id. ib. 9: segundo M. West, a repetição no v. 9 de polykhrýsou, que já se lê no v. 3 (cf. polykhrýson), parece desnecessária, de modo que se possa aceitar a tese de Wecklein segundo a qual polykhrýsou deveria ser corrigido, de modo a escrever-se polyándrou. Tal correção, contudo, é conceitual, não histórica. De fato, é um adjetivo composto homérico, cuja constituição fonética é muito adequada ao verso anapéstico. Assim, ao passo que M. West supõe essential idea de Ésquilo, poderíamos opor-lhe uma tese poética, segundo a qual a repetição do adjetivo no início do poema serviria justamente para inserir o poema na tradição homérica. Daí, poderse-ia supor o efeito do texto de Ésquilo, que assim aplicaria o material da tradição homérica à descrição de episódio contemporâneo.

- demais, a armada de muito ouro significaria que os persas fazem o contrário do que fazem os gregos. Pois estes, como Odisseu, vão a Tróia buscar ouro, ou seja, trazem a riqueza da periferia ao centro; já os persas pretendem que o centro se expanda até a periferia, de modo a constituir um império. Demais, se, na Ilíada, são os gregos que vão até oriente, nos Persas, todavia, é o oriente que vem à Grécia.

3.

- Ésquilo não usa a língua natural, mas a artificial ou kunstsprache; assim, não emprega a palavra ingenuamente, mas dela se vale para construir um significado que deva ser interpretado. É certo que não pode fugir à tradição a que pertence e que deve mesmo inserir-se nela; porém, é certo também que deve intervir nela (cf. G. Nagy, Pindar's Homer). Aliás, a dificuldade de decifrar aquele significado devese, justamente, a que nos faltam os textos que compõem aquela tradição, isto é, os textos todos que se atribuíam, na época de Ésquilo, a Homero.

\section{3.}

- id. Ag. 493-9: o Coro, ao ver o fumo que sobe, conclui que Tróia foi tomada; porém, percebe que esse sinal, que deveria ser auspicioso, também pressagia algo funesto, porque Agamêmnão e Menelau foram sangüinários e, agora, deverão ser castigados por Zeus.

- id. ib.: a poeira que tem sede e o fumo que sobe são casos homéricos. De fato, Homero descreve a poeira quando se refere a alguém que se move rapidamente e, com isso, faz a poeira levantar-se; assim também, diz que Argo é uma cidade que 
tem sede. Demais, Ésquilo refere o fogo (v. 490), a lama (v. 495), a poeira (v. 495) e o fumo (v. 497), o que seria doutrina física de filósofos dos séc. VI-V a.C.. Assim, na verdade, mistura doutrinas filosóficas contemporâneas com a antiga tradição homérica.

- id. ib.: alguns filólogos observam que kapnôi pyrós (v. 497) não faz sentido; pois, se Clitemnestra capta o sinal à noite, não poderia ser sinal de fumo, mas de fogo mesmo; daí, propõem que se corrija kapnôi em panôi. Seja como for, kapnôi, no v. 818, indica a cidade derrotada; demais, em Sept. 493-4, a expressão pyròs kásin designa a relação dos elementos naturais, ou melhor, do fogo e do vapor.

\section{4 .}

- id. Ag. 650-2: diz-se que um acordo foi feito por dois inimigos há muito inconciliáveis, a saber: pelo fogo e mar. De fato, tal acordo é descrito nos v. 655-7, em que se diz que o raio e as ondas compõem uma única tempestade. Assim, Ésquilo interpretaria a tradicional figura fabulosa do Tifão de Hesíodo, que produz tempestades (Hes. Th. 493), segundo a contemporânea doutrina racional dos filósofos dos séc. VI-V a.C., sobretudo de Empédocles de Agrigento.

- em suma, pode-se concluir que Ésquilo refere tanto a antiga tradição homérica quanto as novas doutrinas filosóficas, de modo a fundi-las e, assim, aplicá-las a um caso particular. Daí, pode-se dizer que o Poeta reflete sobre o estatuto da fala.

\section{4. alegoria de Homero}

- segundo Nagy (G. Nagy, Homeric questions), o Homero que chegou a nós é o Homerus restrictus, elaborado por Aristarco, ao passo que o Homero lido no séc. V a.C. é o Homerus auctus, que compreenderia, além dos que temos, os textos do ciclo e outros.

- para denominar a relação entre dois textos, pode-se empregar o termo intertextualidade. Assim, todo texto seria, segundo J. Kristéva e R. Barthes, excrescência de outro, de tal modo que a este fizesse referência. $O$ termo alegoria, porém, poderia empregar-se para designar um texto que retoma outro, não para repeti-lo, mas para fazê-lo dizer algo outro que o que dizia originalmente.

- Aesch. Ag. 1388-92: todo o modo e vocabulário empregado na descrição do assassinato de Agamêmnão são homéricos, uma vez que Ésquilo emprega imagens e frases já antes empregadas por Homero na descrição da morte de algum guerreiro. Por exemplo, no v. 1386, diz-se que Agamêmnão morre apenas com o terceiro 
golpe; ora, em toda a Ilíada e Odisséia, o único guerreiro que sucumbe apenas após o terceiro golpe é Pátroclo, pois, primeiro, Apolo empurra-o; depois, Euforbes fereo; enfim, Héctor mata-o. De fato, se Agamêmnão abateu todos os troianos, abatêlo a ele, o que faz Clitemnestra, seria o maior feito. Por isso Clitemnestra deve matar Agamêmnão segundo os modos dos heróis homéricos. Por outro lado, as gotas de sangue rosa (v. 1390) parecem ter conotação sexual. De fato, Clitemnestra mata o marido como se o castrasse, pois os gregos só puderam chegar a Tróia e vencer os troianos porque Agamêmnão, antes, matara Ifigênia. Uma vez, porém, que tal episódio não consta em Homero, Ésquilo, ao descrever o assassinato de Agamêmnão à maneira homérica, estaria a aplicar Homero a caso estranho a este.

\section{$2^{\mathrm{a}}$ aula (11/9):}

- ao analisar um texto, tomamo-lo como mimese, e não como discurso. Modernamente, J.-P. Vernant propõe interpretação histórica do texto. Ora, Vernant é marxista, de maneira que admite que a história se faça por contradições. Assim, considera que a tragédia pertença a um momento histórico em que a reflexão está estabelecida; pois o modelo pragmático da pólis opõe-se ao modelo arcaico do génos, de maneira que o teatro grego não está em paz consigo. De fato, ao passo que o herói fala ático, o Coro fala jônico.

- B. Snell supõe que o sujeito deva ter consciência de si. Na epopéia, porém, o herói não passa de uma coleção de coisas, isto é, do thymós, noós, etc, de maneira que, na passagem da epopéia à tragédia, teria havido progresso. Adkins, porém, admite que somos todos conscientes, e C. Gill pondera que não há necessidade de o sujeito ser consciente de si. Daí, Snell diz que a decisão tomada pelo sujeito na tragédia depende, antes de tudo, da pressão social, e Gill, que o sujeito é suficiente para decidir por si. Para os ingleses, a decisão trágica seria como o sacrifício da liberdade forçado pela necessidade; isso, porém, reduz a decisão trágica a algo muito banal, por supor que a decisão seria, no fundo, falta de escolha. Ora, se bem que apliquem certa visão aristotélica à leitura da tragédia, divergem de Aristóteles; pois este considera, ao contrário, que é do caráter que depende a decisão. - em suma, há visões historicistas, evolucionistas e banalizadoras da decisão ética do sujeito trágico; porém, o que se encena na tragédia seria antes o direito que a decisão.

- ora, o conflito é base e propriedade do discurso trágico. Nenhuma voz pode ter razão. O Coro, voz coletiva, sempre está em desacordo com as das personagens, vozes isoladas. No Coro do Agamêmnão, por exemplo, Ésquilo refletiria sobre o 
consenso do pensamento; pois o Coro, composto de anciãos, que, portanto, não podem agir, mas apenas arrazoar, desenvolve o arrazoado mais coerente possível. - se há a vontade de Zeus, há a necessidade; daí, quem obedece àquela vontade, age de acordo com o direito, de maneira que o direito é negação daquilo mesmo a que se aplica. Ártemis é divindade inferior a Zeus, de maneira que não pode oporse à vontade dele; daí, a lógica de Ártemis aplicada ao sacrifício de Ifigênia nada tem que ver com o direito.

\section{$3^{\mathrm{a}}$ aula (17/9):}

- o conceito de forma simbólica provém de E. Cassirer, segundo o qual só se pode compreender a questão do direito da tragédia se se reflete sobre o sentido da encenação e do diálogo.

- Ésquilo entende Zeus como conceito unificador, de modo a afastar-se da teologia hesiódica.

- o Coro, primeiro, admite que seja justo Agamêmnão pedir o sangue da filha (cf. Aesch. Ag. 215: thémis); depois, porém, condena a decisão do pai. Ora, uma vez que Agamêmnão apresenta argumentos fortes com que justifique o sacrifício da filha, não se entende bem por que o Coro o condena. Alguns concluem simplesmente que o Coro seja tolo; outros, que o Coro condene, não o ato, mas as palavras de Agamêmnão, demasiado ferozes. Demais, o Coro admite que Agamêmnão se tenha curvado à necessidade (cf. id. ib. 218: anágkas), o que seria citação de Teógnide, que diz que aquele que se curva à necessidade é sábio; o Coro, porém, julga Agamêmnão criminoso, o que seria contraditório.

- só no v. 1343 do Agamêmnão se narra o assassinato de Agamêmnão, de maneira que tudo o que se narra antes seria, do ponto de vista aristotélico, inútil ao mythos. - a tomada de Tróia é uma necessidade, e a luta e o massacre são preços que se devem pagar à necessidade e, daí, seriam justos; porém, o sacrifício de Ifigênia talvez fosse um preço excessivo. Homero, embora não refira o sacrifício de Ifigênia, narra o momento em que os chefes gregos e troianos interrompem a guerra para propor uma decisão jurídica tomada a partir do combate individual de Menelau e Páride, mas os deuses não toleram tal procedimento, justamente porque reivindicam o pagamento da guerra feito à custa de morte e massacre.

- Clitemnestra, que é a única representante da casa, rejeita a vingança do daímon; logo, não está ao lado da justiça, porque pretende matar por vingança pessoal. $\mathrm{Na}$ verdade, o passo em que declara ter abdicado da vingança do daímon seria irônico (cf. id. ib. 1567-76). 
- os historiadores consideram que a Orestéia obedece a um padrão jurídico, e não que se submeta a uma vingança repetida indefinidamente. Na verdade, a vingança seria, primeiro, batalha de clãs diversos e, depois, batalha que pretenderia compensar a violência com a não-violência. Assim, a Orestéia não trataria a vingança, mas um sistema jurídico de compensação; ou melhor, trataria a perversão de tal sistema, pois que trataria a vingança perpetrada no seio de um mesmo clã e a violência paga com violência.

- o caráter pessoal da vingança de Clitemnestra assinala-se pela kháris que acompanha o assassinato de Agamêmnão. Ora, isso talvez seja reminiscência de algum padrão hesiódico; pois, na Teogonia, o mesmo ato da castração de Úrano gera, de um lado, as Erínies e, de outro lado, Afrodite, que é acompanhada pelas Khárites. - na Atenas do séc. V a.C. não havia pena para o parricídio, pela simples razão de que só a família podia mover a ação acusatória, e, no parricídio, a família é justamente vítima e assassino. Os sofistas assinalaram essa lacuna do direito, e Platão, nas Leis, identifica o parricídio com assassinato comum, a fim de suprir a lacuna. Seja como for, na época de Ésquilo, Orestes não podia ser julgado no Areópago por ter matado a mãe.

\section{$4^{\text {a }}$ aula $(18 / 9)$ :}

[continuação da $3^{\mathrm{a}}$ aula]

- isso de as Mênades vigiarem os mortais inserir-se-ia na teologia hesiódica, que admite que os daímones vigiam os homens (cf. AEsCH. Eum.: brotoskóron mainádon [...] kótos pánt' ephéso móron).

- no julgamento de Orestes, Apolo relembra a doutrina tradicional, segundo a qual o filho provém tão-só da semente do pai, ao passo que a Empédocles de Agrigento parecia que o filho provinha de ambas as sementes do pai e da mãe.

- o escopo de Pálade Atena é situar as Eumênides num lugar, porque, enquanto permanecem nas trevas, estão fora do mundo.

- as Erínies, primeiro, declaram que apenas os crimes consangüíneos são de sua alçada; no fim da peça, porém, admitem que qualquer crime seja de sua competência. 


\section{[4 $4^{\mathrm{a}}$ aula]}

- de dois modos distintos Ésquilo usa do mito. Assim, nos Sete contra Tebas, de um lado, o mito é o que é, ou melhor, o caso narrado restringe-se a Tebas, de maneira que não se pode transpor o caso para a discussão da natureza da política geral. Nos Persas, de outro lado, a guerra de gregos e persas só pode ser compreendida a partir da Ilíada, na medida em que os Persas seriam uma verdadeira interpretação daquele poema.

- muito pouco chegou até nós do que foi escrito sobre política entre Solão e Ésquilo. Ora, Solão defende posição política que bem se aplicaria ao caso de Etéocles. Segundo tal posição, o legislador, à medida que define o todo da cidade, padece a ameaça desta; já Zeus ordena o mundo sem ser ameaçado por este. Ora, Tróia foi condenada pelos deuses, de maneira que tinha de ser destruída; Atenas, porém, diz Solão que, embora não tenha sido condenada pelos deuses, é ameaçada pelos próprios cidadãos. Na verdade, Solão assinala mesmo a discrepância entre a bênção dos deuses, favorável à cidade, e a loucura dos cidadãos, perigosa para ela (Sol. frg. West 4). Os sofistas, porém, invertem o problema; pois, ao passo que Solão acusa os cidadãos de pensar no interesse próprio, Protágoras arrazoa que, se cada um buscar o interesse próprio, a soma dos interesses dos cidadãos coincidirá com o interesse da cidade.

- em 1848, um filólogo alemão acusou a existência de uma didascália, segundo a qual os Sete contra Tebas teriam sido a terceira peça de uma trilogia composta assim: $1^{\circ}$ Laio; $2^{\circ}$ Édipo; $3^{\circ}$ Sete contra Tebas. Chama a atenção, antes de tudo, que, no início da peça, apenas Etéocles fale, ao passo que, na peça de Eurípides, ambos os irmãos falam; pois seria de supor que um só homem pudesse reivindicar o interesse do todo quando este está dividido. Ora, Etéocles diz que o rei vigia a cidade sem dormir, o que lembra o olho que tudo vê do Crono de Hesíodo. Seja como for, a concepção política dos Sete contra Tebas concebe o todo a partir do indivíduo, de maneira que se possa dizer antes monológica que política.

- F. Zeitlin (F. Zeitlin, Playing the other) pretende demonstrar que cada cidade é caracterizada de modo particular nas tragédias gregas. Tebas, por exemplo, seria uma esfera que integrasse as partes num todo; de fato, Tirésias é homem e mulher, e também Dioniso, homem e mulher.

- não há oposição ao mito; pois, mesmo quando Hécuba, nas Troianas de Eurípides, roga Zeus como éter e sensatez, e Menelau se espanta com tal modo de se referir ao deus, trata-se tão-só de rogar um deus, ou melhor, o que conta, ao fim e ao cabo, é a oração ao deus. 
- uma dificuldade dos Persas é que representam um caso contemporâneo de acordo com as regras da tragédia. Ora, assim como, segundo Hesíodo, a raça dos heróis termina com a tomada de duas cidades, de Tróia e de Tebas, assim a era dos persas terminaria com a tomada de Salamina. Outra dificuldade é que, se se toma Xerxes por um homem mau, a peça seria, segundo Aristóteles, falha, porque seria a representação de um homem mau que chega a um fim mau.

- alguns supõem que o público de Ésquilo risse ante a encenação de persas derrotados por eles, justamente porque se lê, na peça, que a derrota faz o inimigo rir; porém, toda a elocução e métrica seriam avessas ao riso. Ora, os Persas seriam uma experiência inédita dos gregos, porque proporiam a descentralização do público, por meio da qual este pudesse ver-se do ponto de vista do outro. Na verdade, na peça, só os persas têm nome próprio, ao passo que os gregos são todos anônimos. - que Xerxes atravesse o mar sem pedir permissão a Posidão (cf. AEsCH. Pers. 739. 52) seria mais uma prova de que aquele vê o mundo indistintamente, admitindo um contínuo entre terra e mar. Assim também, a expansão dos persas não distingue entre poder central persa e poder periférico estrangeiro; ao contrário, admitiria que o poder persa pudesse expandir-se indefinidamente, de modo a transformar todos os povos vizinhos em extensão do poder persa (cf. id. ib. 864-70). Ora, tal concepção política poderia depender da concepção cosmológica de Anaxágoras de Clazômenas, segundo a qual o noûs, primeiro, se expande do centro para a periferia e, depois, retorna de cá para lá.

\section{$5^{\mathrm{a}}$ aula $(24 / 9)$ :}

[continuação da $4^{\mathrm{a}}$ aula]

- nos Persas, Ésquilo constrói uma verdadeira interpretação da guerra de gregos e persas, elaborando os argumentos de Xerxes. Isso, porém, não significa que aquela tragédia não seja um discurso autônomo; pois os Persas não se apresentam como um conceito, isto é, uma definição da guerra, mas aplicam conceitos às personagens, ou melhor, mostram como cada personagem reage a cada conceito. Porém, uma vez que, antes de Ésquilo, não havia discurso prosaico que representasse a história toda - pois Heródoto é posterior a ele, e Hecateio de Mileto apenas esboça a empresa -, o Tragediógrafo devia recorrer ao mito. Demais, uma vez que o mito já era explicado segundo alegoria física - Metrodoro de Lâmpsaco, por exemplo, traduzia os heróis em elementos da natureza -, o Tragediógrafo podia construir as personagens de acordo com os elementos da natureza; assim, quiçá, Xerxes desenvolve seu arrazoado em Pers. 739-52. 
- há muitas relações entre Ésquilo e Homero, ou melhor, entre Ésquilo e a poesia homérica; por exemplo, em Pers. 787, segundo P. Rousseau. Pois, lá, Dario adverte de que não se deva jamais atacar a Hélade, uma vez que a terra mesma é aliada dos gregos: autè gár he gê xýmmakhos keínois pélei (ib. 792); kteínousa limôi toùs hyperpóllous ágan (ib. 794). Ora, o mais das vezes, explica-se o passo dizendo-se que a Hélade é uma terra hostil; porém, pode-se ver no passo uma referência mítica, já que, segundo os Cantos cíprios, a terra se dói porque sobrecarregada dos numerosos homens que a habitam.

- uma dificuldade dos Persas, porém, consiste em identificar o que haveria de triste na peça. Pois, se são tragédia, deveriam produzir terror; se, porém, encenam a derrota dos inimigos, deveriam fazer o público ateniense rir, e não chorar. Ora, chama a atenção que os gregos não sejam nomeados individualmente na peça, de maneira que às ações individuais dos persas se oporia a ação coletiva dos gregos. Daí, poder-se-ia concluir que os Persas fariam o público chorar, não a desventura dos persas, mas a desventura do indivíduo.

\section{$\left[5^{\mathrm{a}}\right.$ aula]}

- das edições modernas dos textos gregos, as notas gramaticais mantêm-se sempre atuais, pois os filólogos contemporâneos podem concordar com os do séc. XIX ou mesmo com os do séc. XVI; já as notas históricas ou mitológicas são, não raro, superadas. Assim, da ed. G. Hermann de Hesíodo (1852), por exemplo, as notas gramaticais são, hoje, inteiramente válidas, mas as alegóricas parecem equivocadas. Das edições contemporâneas dos tragediógrafos gregos mencionem-se estas: de Ésquilo, a ed. M. West (Teubner); de Sófocles, a ed. H. Lloyd-Jones (Oxford) e a ed. R. Dowe (Teubner); de Eurípides, a ed. J. Diggle (Oxford). Tais edições são notáveis pelo aparato crítico; porém, dos 150 manuscritos da tríade bizantina de Ésquilo, por exemplo, isto é, do Prometeu, Sete contra Tebas e Persas, apenas trinta foram lidos até hoje. Demais, a escola filológica que remonta a Willamowitz e Fraenkel atomiza-se em comentários textuais, de modo a esquecer-se da totalidade da obra; já a escola de Page, em que se filiaria West, atenta para o todo da obra. - o Filoctetes foi a última peça de Sófocles; do Filoctetes de Eurípides, a propósito, não nos resta mais que o resumo de Dião o Crisóstomo. A versão de Sófocles diverge da mais tradicional. Assim, segundo esta, após o oráculo que declara que o sucesso dos gregos depende da presença de Filoctetes e Neoptólemo, Diomedes é que vai buscar aquele, e Odisseu, este. Segundo os tragediógrafos, porém, Diomedes não participa da empresa, e é Odisseu que, já acompanhado de Neoptólemo, vai 
buscar Filoctetes. Assim também, apesar de Homero chamar Lemno a bemconstruída (cf. Hom. Il. XXI 40: Lêmnon euktiménen), Sófocles representa-a como ilha anecúmena, de maneira a romper brutalmente com a tradição.

- Soph. Phil. 35-6: quando Neoptólemo refere a madeira (cf. autóxylon), o mau artesão (cf. phlaurourgô̂) e as pedras ígneas (cf. pyreîa), estaria a referir a doutrina política de Protágoras, que refere o artesanato da madeira ou xylourgía. Na verdade, o início do Filoctetes seria, antes de tudo, referência ao início do Prometeu agrilhoado de Ésquilo. Daí, porém, pode-se perguntar qual seria o vínculo entre as duas peças e a doutrina política de Protágoras, ou melhor, a fábula de Prometeu narrada pela personagem deste no Protágoras de Platão. Ora, segundo tal fábula, Hermes dá a todos os homens o mesmo quinhão de díke e aidós, que são bem o que Odisseu deverá negar no fim do Filoctetes, ao sugerir a Neoptólemo que engane Filoctetes. De fato, uma vez que não pode nem persuadir (peithó) nem forçar (bía) Filoctetes a segui-lo, a Odisseu só resta o dolo (dólos). Nos v. 77-80, ademais, opõem-se sophisthênai (v. 77), phýsei (v. 79), pephykóta (v. 79), tekhnâsthai (v. 80).

\section{$6^{\mathrm{a}}$ aula $(25 / 9)$ :}

[continuação da $5^{\text {a }}$ aula]

- no fim do Filoctetes, ao entrar o deus ex machina, Héracles diz que, para Zeus, o que conta, sobretudo, é a piedade; no meio da peça, porém, Odisseu diz que é necessário esquecer por um momento a piedade.

- à primeira vista, Filoctetes é como que a caricatura do herói trágico, uma vez que despropositadamente não se deixa convencer, ou melhor, não rebate os argumentos alheios com nenhum argumento próprio, apenas se recusa a concordar com aqueles. Quando se interroga, dizendo: tí dráso? (v. 1350), põe-se como verdadeira personagem dramática. De fato, segundo B. Snell (B. Snell, Aischylos und das Hahdeln im Drama), a pergunta ti práttein é própria do herói trágico, ao passo que a pergunta ti páskhein, do Coro. Seja como for, Filoctetes hesita em deixar-se convencer pelo arrazoado de Neoptólemo. Se se observa melhor, porém, vê-se que Filoctetes, sobre mostrar-se avesso à argumentação de Odisseu, refuta-a, sim, com contraargumentos próprios. Assim, em primeiro lugar, contra os que entendem que Filoctetes é insensível aos argumentos de Odisseu, é de reparar que o mesmo Filoctetes diz que os Atridas é que são irredutíveis. Demais, emprega em seu arrazoado as palavras mesmas de Odisseu. Pois, assim como este opõe phýsis e tékhne, assim Filoctetes refere a gnóme, isto é, a natureza dos Atridas, acusando-a, primeiro, de mãe de males e, depois, de ter sido educada para fazer coisas más (cf. v. 1361: 
paideúei), o que é um artifício (v. 1360-1). Demais, Filoctetes adverte Neoptólemo de que este não é mau e, por isso, não pode pôr-se ao lado dos Atridas, maus. Seja como for, Filoctetes cede, enfim, ao arrazoado de Héracles que, todavia, concorda em tudo com o de Odisseu, de maneira que há desenlace ao nível do mito, mas aporia ao nível do arrazoado.

\section{$\left[6^{\mathrm{a}}\right.$ aula]}

- assim como Aristófanes parodia a tragédia, assim Eurípides parodiaria a comédia nas Bacantes (441 a.C.). Ora, estas teriam integrado uma trilogia à qual teria pertencido também a Ifigênia em Áulide. Daí, a primeira dificuldade residiria nisto de, na Ifigênia em Áulide, não intervir deuses, e, nas Bacantes, o deus ser onipresente. - nos dois primeiros versos das Bacantes, propõe-se uma interpretação etimológica do nome Dioniso que não é gratuita, a saber: Diòs paîs, pois toda a peça depende, justamente, da recusa de Penteu a aceitar a paternidade divina de Dioniso.

- de um lado, Penteu, embora duvide da divindade de Dioniso, é pio, pois a dúvida assenta-se na recusa a admitir que Zeus se tivesse enamorado de uma simples mortal. De outro lado, Dioniso acusa a própria Hera de hybristés (v. 9), o que seria, em princípio, impossível, já que hýbris é a soberba do homem, contrária aos deuses. - de dois modos pode-se analisar esta frase: dề gàr pólin ténd' ekmatheîn, kei' mè gélei, / atéleston oûsan tôn emôn bakkheumáton. Pois, de um modo, atéleston oûsan seria aposto de pólin, e ekmatheîn seria intransitivo, de modo que a frase se traduzisse assim: "deve-se ensinar esta cidade [...], ainda que não seja iniciada [...]". De outro modo, atéleston oûsan seria complemento de ekmatheîn, de maneira que a frase se traduzisse assim: "deve-se ensinar a esta cidade que ela não é iniciada". Ora, a segunda análise parece mais adequada, por considerar o verbo da frase transitivo; porém, no contexto, a proposição é paradoxal, pois Dioniso não poderia dizer que a cidade não é iniciada, uma vez que ele mesmo tornara todas as mulheres Mênades. Ora, o paradoxo consistiria em que Dioniso teria tornado todas as mulheres Mênades justamente para que aprendessem que desconheciam os mistérios dionisíacos.

- nos v. 292-7, Tirésias vale-se da etimologia para explicar a fábula do nascimento de Dioniso e, assim, ameniza os inverossímeis da fábula. Pode-se dizer que, ao mudar a fábula por meio da etimologia, Dioniso recorre ao expediente alegórico dos filósofos, intérpretes de fábulas. Porém, ao passo que estes traduzem a fábula teológica em arrazoado físico ou ético, Tirésias traduz a fábula teológica noutra teológica, ou melhor, a fábula teológica inverossímil noutra teológica verossímil. 
- a paracomédia constaria, por exemplo, do passo em que Penteu contempla as Mênades, pois seria cômico dizer que enxerga dois sóis; ou ainda, que os cabelos lhe atrapalham a visão, como se fosse mulher.

MARCOS MARTINHO DOS SANTOS Faculdade de Filosofia, Letras e Ciências Humanas Universidade de São Paulo 